\title{
Assessment of per se performance, combining ability, hybrid vigour and reaction to major diseases in pigeonpea [Cajanus cajan (L.) Millsp.]
}

\author{
Yamanura $^{1 *}$, R. Lokesha ${ }^{2}$, V. Kantharaju ${ }^{3}$ and S. Muniswamy ${ }^{1}$ \\ ${ }^{1}$ Agricultural Research Station, Gulbarga 585101(Karnataka), INDIA \\ ${ }^{2}$ Department of Genetics \& Plant Breeding, College of Agriculture, UAS, Raichur - 584102 (Karnataka), INDIA \\ ${ }^{3}$ Krishi Vigyan Kendra, Gangavati-584129 (Karnataka), INDIA \\ *Corresponding author. E-mail: yaman3181aug8@gmail.com
}

Received: June 15, 2015; Revised received: January 18, 2016; Accepted: April 9, 2016

\begin{abstract}
An experiment was carried out using seven cytoplasmic-genetic male sterile (CGMS) lines as females and seven diversified testers as males in a line $\times$ tester design. The analysis of variance for parents, females $x$ males, hybrids and parents vs hybrids showed significant differences for almost all characters studied indicating the presence of sufficient variability among parents. Analysis of variance for combining ability revealed that mean squares due to females and line $x$ tester interaction were significant for most of the characters. Thereby it is suggested that the variation in hybrids in respect of seed yield may be strongly influenced by the female lines. Analysis of variance revealed that the ratio of variance due to GCA to SCA was less than unity for all the characters indicating that these traits may be under the influence of non additive gene action and these characters are more likely to be improved through heterosis breeding. The gca effects of parents revealed that ICPA-2043, ICPA-2047, ICPA-2078, AKT-9913, BDN-2 and GRG-811 were good general combiners for seed yield and it's direct components. The top three crosses exhibiting high specific combing ability effects along with their Per se performance, standard heterosis and gca status of the parents indicated that the cross combinations ICPA-2092 x GRG-811, ICPA-2043 x ICP-7035 and ICPA-2047 x RVKP-261 were good specific combiners for seed yield. These parental combinations are being used for exploitation of hybrid vigour. The good general combiners (ICPA-2043, ICPA-2047, ICPA-2078, AKT-9913, BDN-2 and GRG-811) and promising crosses viz. ICPA-2047 x GRG-811 and ICPA-2047 x BDN-2 were resistant for SMD and Fusarium wilt diseases, having high mean performance, positive sca effects for seed yield were identified from the present investigation and these may be useful in future breeding program.
\end{abstract}

Keywords: Cajanus cajan, Combining ability, Hybrid vigour, Per se, Line X Testers

\section{INTRODUCTION}

Pigeonpea (Cajanus cajan (L.) Millsp.) is a perennial shrub belong to economically important tribe Phaseoleae and the subtribe Cajanine. It is an important grain legume mostly being cultivated in Africa, Asia and Americas. The global pigeonpea area, production and yield (in 2013) was $\sim 6.22 \mathrm{mha}, \sim 4.74 \mathrm{MT}$ and 762.4 $\mathrm{kg}$ ha-1respectively (FAOSTAT 2015). During 2013, $\sim 83.09 \%$ of global pigeonpea production and $\sim 85.50 \%$ of area was in Asia, $14.34 \%$ and $12.19 \%$ in Africa, $2.57 \%$ and $2.31 \%$ in Americas (FAOSTAT 2015). The major pigeonpea producing countries include India (63.74\% of global production), Myanmar (18.98\%), Malawi (6.07\%), Tanzania (4.42\%) and Uganda $1.98 \%$ ). In India pigeonpea was cultivated on $4.65 \mathrm{mha}$ with a total production of 3.02 MT and yield of 650.0 $\mathrm{kg}$ ha-1during 2013(Laxmipathi et al., 2015).

It is grown as sole crop or intercrop with urdbean, mungbean, castor, sorghum, soybean, cotton, maize and groundnut in different states like Maharashtra, Karnataka, Andhra Pradesh, Madhya Pradesh, Uttar Pradesh, Gujarat, Jharkhand, Rajasthan Odisha, Punjab and Haryana. Pigeonpea is mostly consumed as dry split dhal besides several other uses of various parts of pigeonpea plant. It is an excellent source of protein (20 $-22 \%$ ), supplementing energy rich cereal diets in a mainly vegetarian population. Pigeonpea is a multipurpose crop that fits very well in the context of sustainable agriculture. In addition to food, it can be used as fodder, feed, fuel, functional utility (for making baskets, huts, fences, etc.), fertilizer (fixes atmospheric nitrogen and releases phosphorus), forest use (re-forestation, lac production), and even for pharmaceutical purposes. However, the current production of pigeonpea in India cannot meet the domestic demand leading to a decrease in per capita availability of pigeonpea from $70 \mathrm{gm}$ to $35 \mathrm{gm}$. Despite the fact that a large number of high yielding varieties and have been released, productivity in the crop remains stagnant around $700 \mathrm{~kg}$ ha-1 as compared to its potential yield (2500-3000 kg ha-1). This gap may be attributed to several biotic and abiotic factors. Since it is mainly a rainfed crop, unfavorable rainfall (delayed, erratic, improper distribution) leads to 
Table 1a. Categorization of genotypes for SMD and wilt reaction.

\begin{tabular}{ll}
\hline Percent disease incidence & Reaction scale \\
\hline $0-10 \%$ of plant infected & Resistant \\
$10.1-30 \%$ plants infected & Moderately resistant \\
$30.1-100 \%$ plants infected & Susceptible \\
\hline
\end{tabular}

terminal drought or heavy down pour. Non adoption of improved management practices and lack of proper research and commercial perspective for the crop influence the low productivity to a greater extent (Laxmipathi et al., 2015).

Most of the economic characters like seed yield, number of pods per plant, days to 50 per cent flowering are mostly governed by polygenes and their inheritance is of complex nature. Therefore, before making attempts for improvement of these characters it is essential to know the nature of gene action controlling these quantitative characters. This information will be helpful to breeders in devising appropriate methods of breeding for crop improvement. A review of literature on quantitative genetics of pigeonpea showed that the presence of significant levels of non additive genetic variation for seed yield which could be profitably exploited through heterosis breeding to increase grain yield (Saxena and Sharma, 1990).

Exploitation of heterosis depends much on general and specific combining ability effects. Combining ability studies are useful in evaluation of the parental lines and their cross combinations, usually this information aids in selection of parents in terms of performance of hybrids and elucidate the nature and magnitude of various types of gene action involved in the expression of quantitative traits (Sony, 2010). Therefore, present study was undertaken to assess per se performance combining ability, hybrid vigour and reaction to major diseases in pigeonpea using seven cytoplasmic genic male sterile lines derived from $\mathrm{A}_{2}$ and $\mathrm{A}_{4}$ cytoplasm and 7 diverse testers crossed in line $\mathrm{x}$ tester design in pigeonpea.

\section{MATERIALS AND METHODS}

The parental material comprised of seven CGMS lines (ICPA-2043, ICPA-2078, ICPA-2047, GT-288A, ICPA-2048-4 ICPA-2092 and GT-307A) used as a females were crossed with seven genotypes viz. GRG811, RVKP-260, RVKP-261, AKT-9913, ICP-7035, RAJA and BDN-2 used as a males in line $\mathrm{x}$ tester mating design during Kharif 2012 and sufficient numbers of hand pollinated seeds were produced. The evaluation experiment was carried out at Agriculture Research Station, Kalaburagi. A total of 49 experimental hybrids, seven females and seven males along with one check (Maruti) were grown in an $8 \times 8$ square lattice design with two replications. Each genotype was sown in two rows of 4.0 meter length with the spacing of 90 $\mathrm{x} 30 \mathrm{~cm}$ between rows and plants respectively.

Observations on five randomly selected competitive plants were recorded for days to $50 \%$ flowering, days
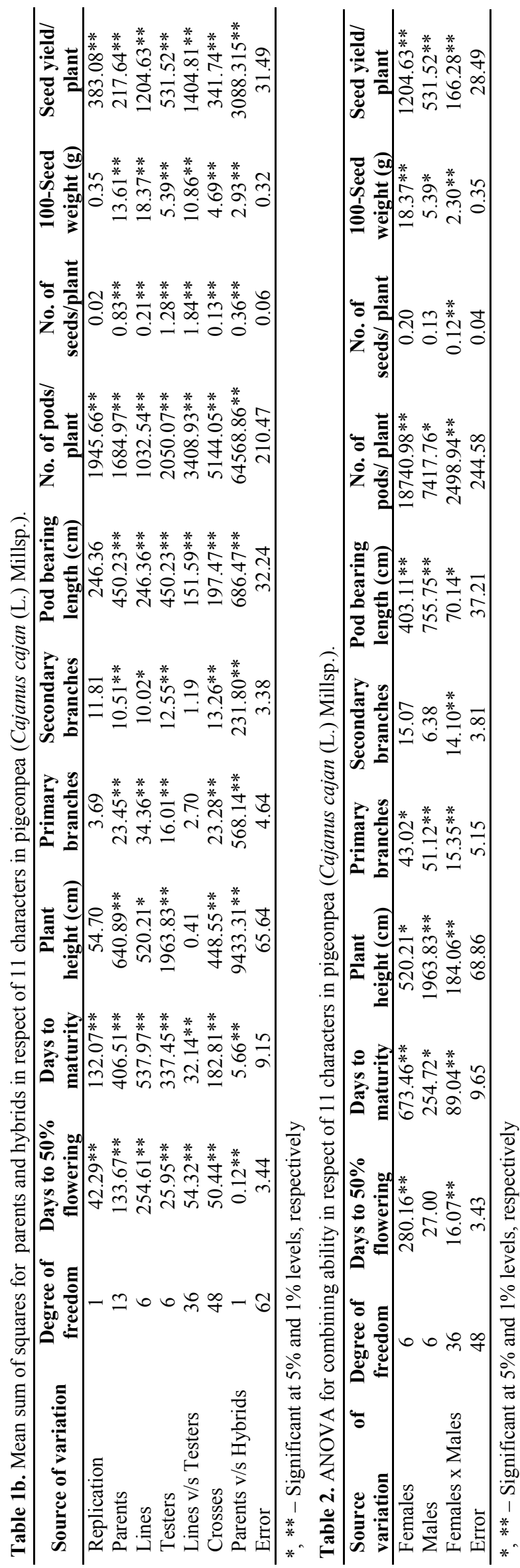
Table 3. Variance due to GCA, SCA and their proportion for 11 different characters.

\begin{tabular}{llccc}
\hline S. N. & Characters & Variance due to GCA & Variance due to SCA & GCA / SCA proportion \\
\hline 1. & Days to 50 per cent flowering & 0.82 & 6.32 & $1: 7.72$ \\
2. & Days to maturity & 2.23 & 39.69 & $1: 17.78$ \\
3. & Plant height (cm) & 6.29 & 57.59 & $1: 9.14$ \\
4. & Primary branches & 0.18 & 5.09 & $1: 27.12$ \\
5. & Secondary branches & -0.02 & 5.14 & $1:-257.20$ \\
6. & Pod bearing length (cm) & 3.03 & 16.46 & $1: 5.43$ \\
7. & No. of pods/plant & 62.97 & 1127.18 & $1: 17.90$ \\
8. & No. of seeds /pods & 0.0003 & 0.04 & $1: 128.66$ \\
9. & 100 seed weight (g) & 0.05 & 0.97 & $1: 17.15$ \\
10. & Seed yield/ plant (g) & 4.17 & 68.90 & $1: 16.49$ \\
\hline
\end{tabular}

to maturity, plant height $(\mathrm{cm})$, number of primary and secondary branches/plant, pod bearing length $(\mathrm{cm})$, number of pods/plant, No. of seeds /pods, 100 seed weight, and seed yield/plant (g). The data was subjected to analysis of variance and combining ability using statistic package WINDOSTAT 8.5 developed by Indostat services, Hyderabad (India). Experimental layout for screening Fusarium wilt was laid out on national wilt sick plot maintained at Agricultural Research Station, Gulbarga during kharif 2013 along with wilt susceptible check (ICP-2376) and resistant check (MARUTI) varieties. A row length of 4 meters each was maintained with spacing of $75 \mathrm{~cm}$ and $30 \mathrm{~cm}$ between the rows and plants respectively. The observations on per cent wilt was recorded at flowering (90 days after sowing) and at physiological maturity (150 days after sowing) stage by counting number of dead plants (due to Fusarium wilt) among the total number of plants present per genotype and per cent disease was estimated.

Experimental layout for screening sterility mosaic disease (SMD) was laid out at Agricultural Research Station, Bidar. Sterility Mosaic disease pressure was created by maintaining four rows of susceptible check (ICP-8863) all around the plot i.e "Infector hedge row technique". Test entries were sown in two rows each and susceptible check was sown after every $10^{\text {th }}$ row. "Leaf Stapling Technique" (Nene and Reddy, 1977) was followed to build the disease incidence. Plants were scored for incidence of SMD at 15 days interval up to maturity stage by counting the healthy plants (no mosaic symptoms) and diseased plants (with mosaic symptoms). Categorization of genotypes for SMD and Fusarium wilt reaction was carried out following the standard scale given in table-1a (Singh et al., 2003).

Percent disease incidence (PDI) was estimated using formulae.

$$
\text { Per cent disease incidence }=\quad \frac{\text { Number of plants infected in row }}{\text { Total number of plants in a row }} \times 100
$$

\section{RESULTS AND DISCUSSION}

The analysis of variance for the mean sum of squares for parents showed significant differences for almost all characters studied indicating the presence of sufficient variability among parents. The interaction between females $\mathrm{x}$ males was significant for days to maturity, pod bearing length, number of pods per plant, number of seeds per pods, 100 seed weight, seed yield per plant and seed yield per hectare. The hybrids showed highly significant differences for all the quantitative traits. Parents Vs hybrids also showed significant difference for all the characters (Table 1b).

Analysis of variance for combining ability revealed that mean squares due to females were significant for all most all the characters except secondary branches and total number of seeds per pods, while mean squares due to males were significant for all the traits except days to $50 \%$ flowering, secondary branches, number of seeds per pods and seed yield per plant. The mean squares due to line $\mathrm{x}$ tester interaction were significant for all the traits. Thereby it is suggested that the variation in hybrids with respect of seed yield may be strongly influenced by the lines. The mean squares due to lines were larger in magnitude for most of the important yield attributes than those for testers indicating greater diversity amongst the lines as compared to testers (Table-2).

Analysis of variance revealed that the ratio of variance due to $G C A$ to $S C A$ was less than unity for all the characters (Table 3 ) indicating that these traits may be under the influence of non additive gene action and these characters are more likely to be improved through heterosis breeding. The above findings are in agreement with the earlier reports of Beekham and Umaharan (2010), Shobha and Balan (2010), Sony (2010), Chethana et al. (2013), Yamanura et al. (2014) and Meshram et al. (2013) also revealed the same results for most of the important characters including seed yield except plant height indicating these traits are under the influence of non additive gene action.

The analysis of variance for combining ability indicated that the mean squares due to general and specific combining ability effects were of both additive and nonadditive gene action. The mean sum of squares due to lines $\times$ testers and their interactions were highly significant for seed yield and it's component characters indicating the importance of sca variance, and consequently the non-additive genetic variation in the inheritance of these characters. The trend recorded was in agreement with the findings of Khorgade et al. (2000), Sunil Kumar et al. (2003) and Sekhar et al. (2004). Vaghela et al. (2009), Sameer Kumar et al. (2009) and Bharate et al. (2011) for seed yield/plant and other 


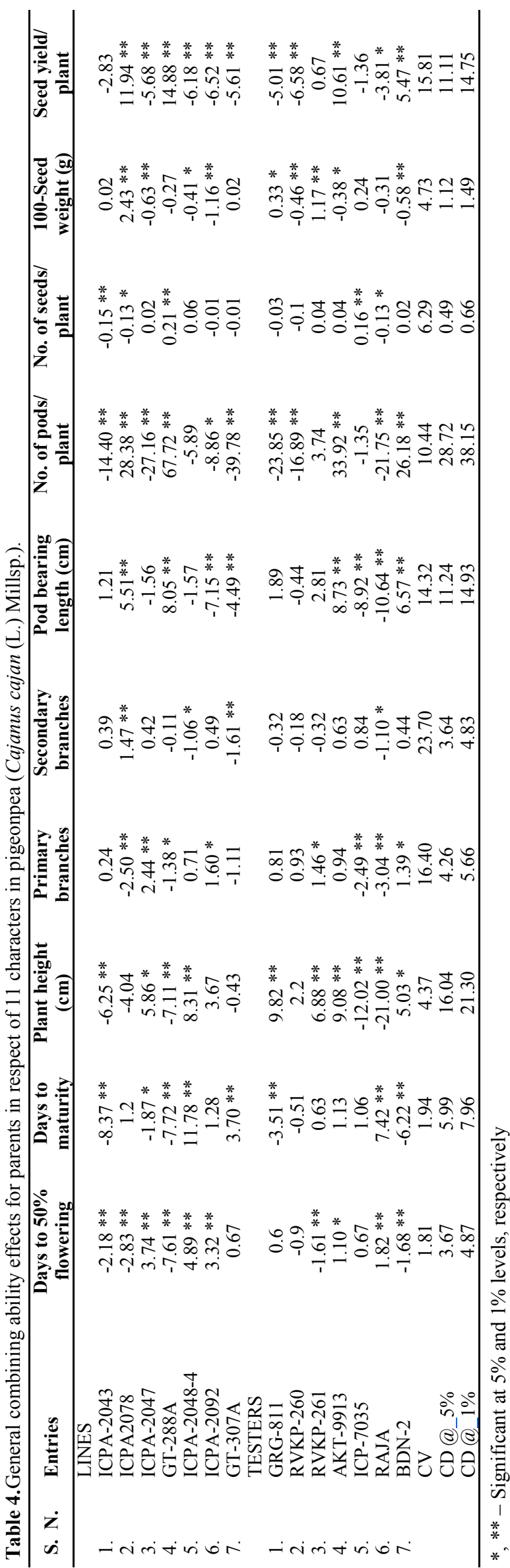

important yield attributes viz., pod bearing length, number of pods per plant and 100 seed weight. Preponderance of non-additive genetic variance has been suggested. On contrary, predominance of additive gene action was obtained by Achamma et al. (1996) and Singh and Srivastava (2001). However, importance of both additive as well as non-additive gene action was recorded by Acharya et al. (2009).

The nature and magnitude of combining ability effects help in identifying superior parents and their utilization in breeding programme. Character-wise estimation of $g c a$ effects of lines and testers is presented in Table- 4. The gca effects of parents revealed that ICPA-2043, ICPA-2047, ICPA-2078, AKT-9913, BDN-2 and GRG-811 were good general combiners for seed yield and it's direct components. The lines GT -288A, ICPA-2043 and ICPA-2078 and testers BDN2, GRG-811 and RVK-261 were good general combiners for days to $50 \%$ flowering and days to maturity, lines ICPA-2047 and ICPA-2048-4 and testers GRG-811 and AKT-9913 for plant height, lines ICPA2047, ICPA-2078 and ICPA-2092 and testers RVK261, ICP-7035 and BDN-2 for number of branches/ plant, lines ICPA-2078 and GT-288A and testers AKT-9913 and BDN-2 for pod bearing length and number of pods/plant, line ICPA-2078 and tester RVK -261 for 100 seed weight (Table 4).

The top three crosses exhibiting high specific combing ability effects along with their Per se performance, standard heterosis and gca status of the parents indicated that the cross combinations ICPA-2092 x GRG811, ICPA-2043 x ICP-7035 and ICPA-2047 x RVKP261 were good specific combiners for seed yield per hectare. These parental combinations are being used for exploitation of hybrid vigour. The cross combination ICPA-2092 x RVKP-261, ICPA-2047x RAJA and ICPA-2078 x GRG-811 were good specific combiners for days to $50 \%$ flowering and maturity as they were showing highly significant negative $s c a$ effect and it is very much suitable to rainfed condition because it has advantage of escaping terminal moisture stress. The crosses GT-288A x ICP-7035, ICPA-2043 x ICP-7035 and ICPA-2043 x RAJA for plant height, ICPA-2078 x ICP-7035 and ICPA-2043 x RAJA for number of primary branches, ICPA-2078 x AKT-9913, GT-307A x BDN-2 and ICPA-2092 x GRG-811 for number of secondary branches, ICPA-2078 x GRG-811, ICPA$2043 \times$ BDN-2 and GT-288A x AKT-9913 for pod bearing length, GT-288A x AKT-9913, ICPA-2043 x BDN-2 and ICPA-2043 x RAJA for number of pods per plant, GT-288A x ICP-7035, ICPA-2043 x RAJA and ICPA-2078 x RAJA for 100 seed weight, ICPA$2078 \times$ AKT-9913, GT-288A x ICP-7035 and ICPA2078 x AKT-9913 for seed yield per plant were found to be useful. The estimates of $s c a$ effects revealed that nine experimental hybrids had significant, desirable and positive sca effects for seed yield/plant. Among these, three best crosses were selected on the basis of 
Yamanura et al. / J. Appl. \& Nat. Sci. 8 (2): 588 - 596 (2016)

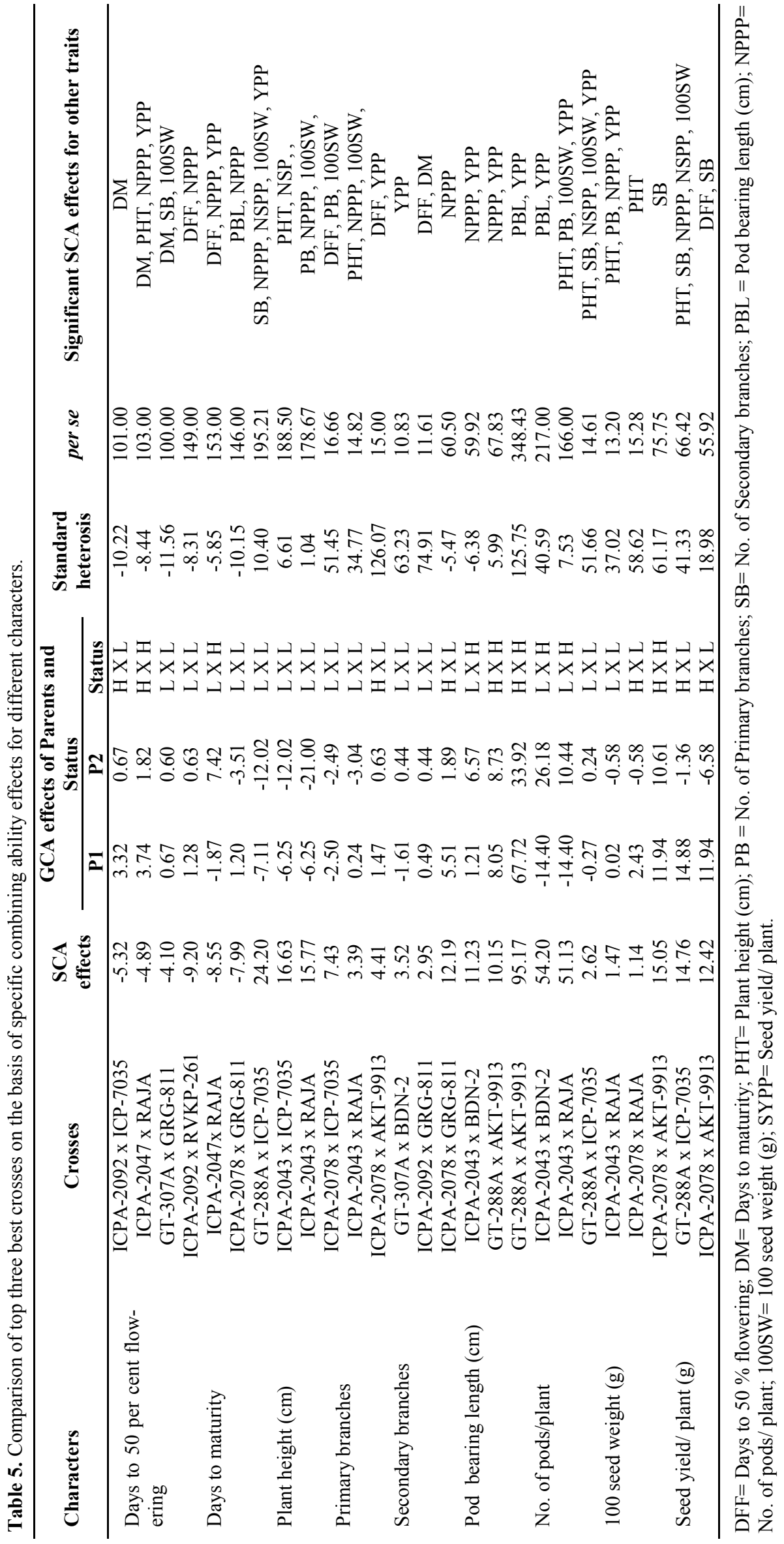




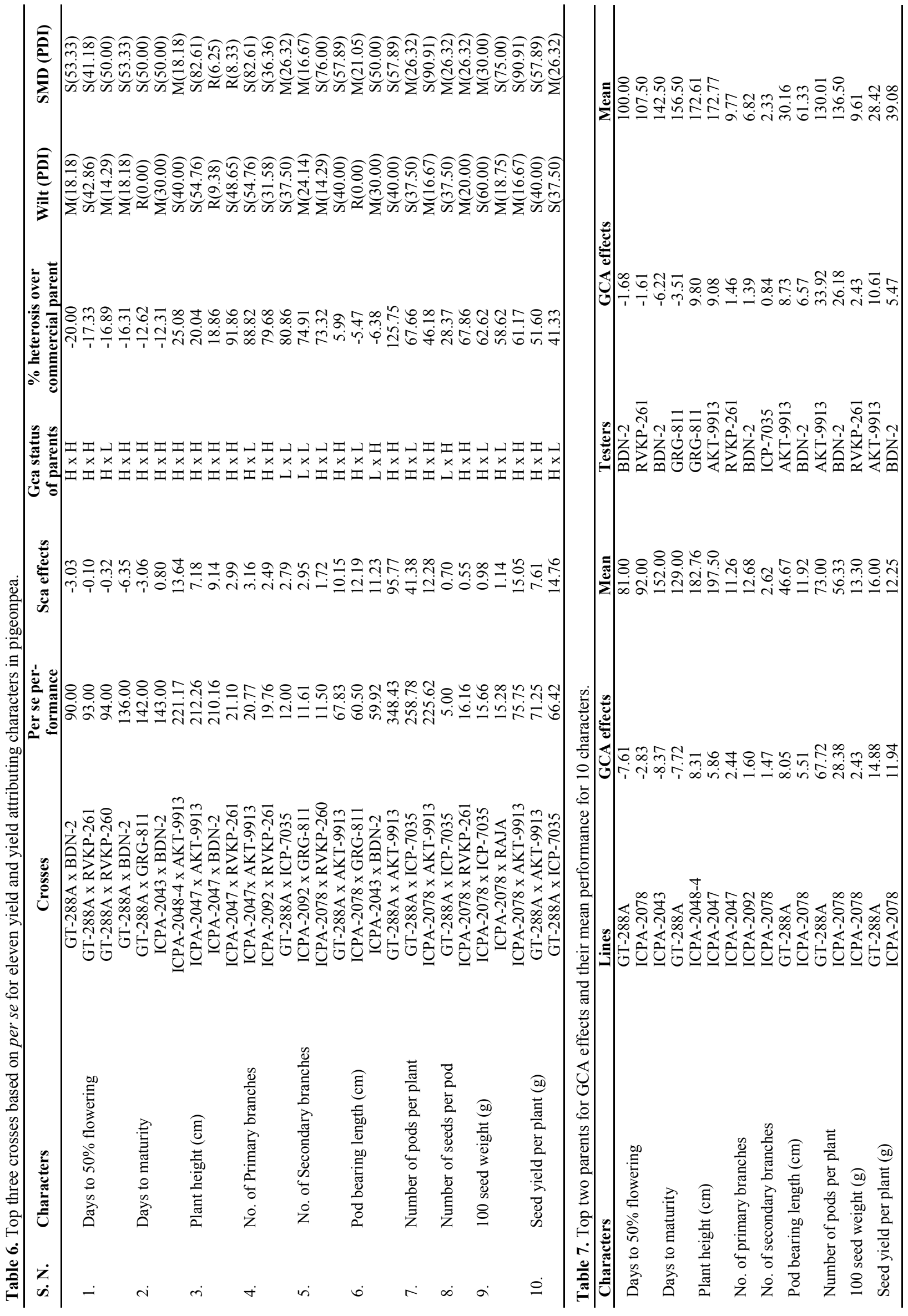


Table 8. Reaction of hybrids and parents to wilt and SMD during Kharif 2013.

\begin{tabular}{|c|c|c|c|c|c|}
\hline \multirow{2}{*}{ S. $\mathbf{N}$. } & \multirow{2}{*}{ Cross name } & \multicolumn{2}{|c|}{ Fusarium Wilt } & \multicolumn{2}{|c|}{ Sterility mosaic disease } \\
\hline & & PDI & Reaction & PDI & Reaction \\
\hline 1. & ICPA-2043 x GRG-811 & 15.79 & $\mathrm{MR}$ & 20.00 & MR \\
\hline 2. & ICPA-2043 x RVKP-260 & 23.53 & MR & 18.18 & MR \\
\hline 3. & ICPA-2043 x RVKP-261 & 59.38 & $\mathrm{~S}$ & 75.00 & $\mathrm{~S}$ \\
\hline 4. & ICPA-2043 x AKT-9913 & 33.33 & $\mathrm{~S}$ & 22.22 & MR \\
\hline 5. & ICPA-2043 x ICP-7035 & 35.71 & $\mathrm{~S}$ & 4.55 & $\mathrm{R}$ \\
\hline 6. & ICPA-2043 x RAJA & 25.93 & MR & 5.56 & $\mathrm{R}$ \\
\hline 7. & ICPA-2043 x BDN-2 & 30.00 & MR & 50.00 & $\mathrm{~S}$ \\
\hline 8. & ICPA-2078 x GRG-811 & 0.00 & $\mathrm{R}$ & 21.05 & MR \\
\hline 9. & ICPA-2078 x RVKP-260 & 14.29 & MR & 76.00 & $\mathrm{~S}$ \\
\hline 10. & ICPA-2078 x RVKP-261 & 20.00 & MR & 26.32 & MR \\
\hline 11. & ICPA-2078 x AKT-9913 & 16.67 & MR & 90.91 & $\mathrm{~S}$ \\
\hline 12. & ICPA-2078 x ICP-7035 & 60.00 & $\mathrm{~S}$ & 30.00 & MR \\
\hline 13. & ICPA-2078 x RAJA & 18.75 & MR & 75.00 & $\mathrm{~S}$ \\
\hline 14. & ICPA-2078 x BDN-2 & 25.00 & MR & 33.33 & $\mathrm{~S}$ \\
\hline 15. & ICPA-2047 x GRG-811 & 8.06 & $\mathrm{R}$ & 5.88 & $\mathrm{R}$ \\
\hline 16. & ICPA-2047 x RVKP-260 & 36.59 & $\mathrm{~S}$ & 73.68 & $\mathrm{~S}$ \\
\hline 17. & ICPA-2047 x RVKP-261 & 48.65 & $\mathrm{~S}$ & 8.33 & $\mathrm{R}$ \\
\hline 18. & ICPA-2047 x AKT-9913 & 54.76 & $\mathrm{~S}$ & 82.61 & $\mathrm{~S}$ \\
\hline 19. & ICPA-2047 x ICP-7035 & 63.16 & $\mathrm{~S}$ & 10.00 & $\mathrm{R}$ \\
\hline 20. & ICPA-2047 x RAJA & 45.45 & $\mathrm{~S}$ & 15.38 & MR \\
\hline 21. & ICPA-2047 x BDN-2 & 9.38 & $\mathrm{R}$ & 6.25 & $\mathrm{R}$ \\
\hline 22. & GT-288A x GRG-811 & 0.00 & $\mathrm{R}$ & 50.00 & $\mathrm{~S}$ \\
\hline 23. & GT-288A x RVKP-260 & 14.29 & MR & 50.00 & $\mathrm{~S}$ \\
\hline 24. & GT-288A x RVKP-261 & 42.86 & $\mathrm{~S}$ & 41.18 & $\mathrm{~S}$ \\
\hline 25. & GT-288A x AKT-9913 & 40.00 & $\mathrm{~S}$ & 57.89 & $\mathrm{~S}$ \\
\hline 26. & GT-288A x ICP-7035 & 37.50 & $\mathrm{~S}$ & 26.32 & MR \\
\hline 27. & GT-288A x RAJA & 60.00 & $\mathrm{~S}$ & 27.78 & MR \\
\hline 28. & GT-288A x BDN-2 & 18.18 & MR & 53.33 & $\mathrm{~S}$ \\
\hline 29. & ICPA-2048-4 x GRG-811 & 27.03 & MR & 28.57 & MR \\
\hline 30. & ICPA-2048-4 x RVKP-260 & 43.59 & $\mathrm{~S}$ & 33.33 & $\mathrm{~S}$ \\
\hline 31. & ICPA-2048-4 x RVKP-261 & 44.44 & $\mathrm{~S}$ & 26.32 & MR \\
\hline 32. & ICPA-2048-4 х AKT-9913 & 40.00 & $\mathrm{~S}$ & 18.18 & MR \\
\hline 33. & ICPA-2048-4 x ICP-7035 & 47.37 & $\mathrm{~S}$ & 27.78 & MR \\
\hline 34. & ICPA-2048-4 x RAJA & 16.00 & MR & 23.53 & MR \\
\hline 35. & ICPA-2048-4 x BDN-2 & 35.90 & $\mathrm{~S}$ & 20.00 & MR \\
\hline 36. & ICPA-2092 x GRG-811 & 24.14 & MR & 16.67 & MR \\
\hline 37. & ICPA-2092 x RVKP-260 & 39.29 & $\mathrm{~S}$ & 31.25 & $\mathrm{~S}$ \\
\hline 38. & ICPA-2092 x RVKP-261 & 31.58 & $\mathrm{~S}$ & 36.36 & $\mathrm{~S}$ \\
\hline 39. & ICPA-2092 x AKT-9913 & 28.57 & MR & 42.11 & $\mathrm{~S}$ \\
\hline 40. & ICPA-2092 x ICP-7035 & 27.78 & MR & 27.78 & MR \\
\hline 41. & ICPA-2092 x RAJA & 56.25 & $\mathrm{~S}$ & 27.27 & MR \\
\hline 42. & ICPA-2092 x BDN-2 & 30.00 & MR & 69.57 & $\mathrm{~S}$ \\
\hline 43. & GT-307A x GRG-811 & 40.91 & $\mathrm{~S}$ & 28.00 & MR \\
\hline 44. & GT-307A x RVKP-260 & 26.92 & MR & 28.57 & MR \\
\hline 45. & GT-307A x RVKP-261 & 29.41 & MR & 21.74 & MR \\
\hline 46. & GT-307A x AKT-9913 & 25.00 & MR & 52.94 & $\mathrm{~S}$ \\
\hline 47. & GT-307A x ICP-7035 & 33.33 & $\mathrm{~S}$ & 15.79 & MR \\
\hline 48. & GT-307A x RAJA & 36.84 & $\mathrm{~S}$ & 28.57 & MR \\
\hline 49. & GT-307A x BDN-2 & 11.76 & MR & 23.08 & MR \\
\hline 50. & GRG-811 & 9.80 & $\mathrm{R}$ & 20.00 & MR \\
\hline 51. & RVKP-260 & 27.78 & MR & 32.00 & $\mathrm{~S}$ \\
\hline 52. & RVKP-261 & 44.74 & $\mathrm{~S}$ & 50.00 & $\mathrm{~S}$ \\
\hline 53. & AKT-9913 & 33.33 & $\mathrm{~S}$ & 66.67 & $\mathrm{~S}$ \\
\hline 54. & ICP-7035 & 88.89 & $\mathrm{~S}$ & 4.55 & $\mathrm{R}$ \\
\hline 55. & RAJA & 85.71 & $\mathrm{~S}$ & 4.17 & $\mathrm{R}$ \\
\hline 56. & BDN-2 & 4.35 & $\mathrm{R}$ & 57.14 & $\mathrm{~S}$ \\
\hline 57. & ICPA-2043 & 20.45 & MR & 27.78 & MR \\
\hline 58. & ICPA2078 & 9.68 & $\mathrm{R}$ & 28.57 & MR \\
\hline 59. & ICPA-2047 & 9.80 & $\mathrm{R}$ & 0.00 & $\mathrm{R}$ \\
\hline 60. & GT-288A & 39.29 & $\mathrm{~S}$ & 33.33 & $\mathrm{~S}$ \\
\hline 61. & ICPA-2048-4 & 22.50 & MR & 25.00 & MR \\
\hline 62. & ICPA-2092 & 6.45 & $\mathrm{R}$ & 33.33 & $\mathrm{~S}$ \\
\hline 63. & GT-307A & 20.51 & MR & 14.29 & MR \\
\hline 64. & MARUTI (WRC and SSC) & 6.51 & $\mathrm{R}$ & 100 & $\mathrm{~S}$ \\
\hline 65. & ICP-2376(WSC) & 92.5 & $\mathrm{~S}$ & 78.5 & $\mathrm{~S}$ \\
\hline
\end{tabular}

WSC: Wilt susceptible check; R: Resistant; WRC: Wilt resistant check; M: Moderately resistant; SSC: SMD susceptible check; S: Susceptible. 
per se performance for ascertaining their association with $s c a$ effects of seed yield per plant and its attributes (Table 5).

Out of three crosses showing high mean and significant positive sca effects for seed yield along with their per se performance as well as gca effects of parents and their significant response to other characters are presented in Table 6. Out of three crosses showing high mean and significant positive $s c a$ effects for grain yield, two crosses ICPA-2043 x ICP-7035 and ICPA2047 x RVKP-260 involved high $\times$ low gca parents and the remaining cross ICPA-2092 x GRG-811with low $\mathrm{x}$ low $g c a$ effects of parents. These results were also in conformity with those of Baskaran and Muthiah (2007), Meshram et al. (2013), Chethana et al. (2013) and Yamanura et al. (2014). Better performance of hybrids involving high $\mathrm{x}$ low or low $\mathrm{x}$ low general combiners indicated dominance $\mathrm{x}$ dominance (epitasis) type of gene action. The crosses showing high sca effects involving one good general combiner indicated additive $\mathrm{x}$ dominance type gene interaction which exhibit the high heterotic performance for yield and yield related traits.

The hybrid derivatives of crosses such as ICPA-2047 $\mathrm{x}$ GRG-811 and ICPA-2047 x BDN-2 were resistant for both the diseases with per cent disease incidence value of $8.06 \& 9.38$ for Fusarium wilt and $5.88 \& 6.25$ for SMD respectively (Table 8 ); these findings were in agreement with Sharma et al. (2013) and resistant sources identified in the field were confirmed in the greenhouse using a root dip screening technique for FW and a leaf stapling technique for SMD. Six accessions were found resistant to FW $(<10 \% \mathrm{PDI})$. High level of resistance to SMD was found in 24 accessions $<10 \%$ PDI).

\section{Conclusion}

The results suggested that hybrid derivatives of crosses ICPA-2047 x GRG-811 and ICPA-2047 x BDN-2 were resistant for both the diseases, having high mean performance, positive $s c a$ effects for seed yield. Their significant response to other related traits had necessarily involved both or at least one parent as good combiner which could be commercially exploited for heterosis by taking advantage of natural out crossing in pigeon pea.

\section{ACKNOWLEDGEMENTS}

Sincere thanks to National Food Security Mission, New Delhi, International Crop Research Institute for Semi-arid and Tropics, Hyderabad and Gujarat Agricultural University for having provided seed materials and financial support under the project entitled "Taking pigeonpea projects to the door steps of the farmers".

\section{REFERENCES}

Achamma, O., Nambhoodiri, K.M.N. and Vijaykumar, N.
(1996), Combining ability in pigeonpea (Cajanus cajan (L.) Millsp.). J. Trop. Agric. 34(1):1-5.

Acharya, S., Patel, J.B., Tank, C.J. and Yadav, A.S. (2009), Heterosis and combining ability studies in Indo-African crosses of pigeonpea. J. Food Legume., 22(2): 91-95.

Baskaran, K. and Muthiah, A.R. (2007). Combining ability studies in pigeonpea. Legume Research. 30: 67-69.

Beekham, A.P. and Umaharan, (2010). Inheritance and combining ability studies of pod physical and biochemical quality traits in vegetable pigeonpea. Euphytica, 176:36-47.

Bharate, B.S., Wadikar, P.B. and Ghodke, M.K. (2011). Studies on combining ability for yield and its components in pigeonpea. Journal of Food Legumes. 24(2): 148-149.

Chethana, C.K., Dharmaraj, P.S., Lokesha, R., Girisha, G., Muniswamy, S., Yamanura, Niranjana k. and Vinayaka, D.H. (2013). Genetic analysis for quantitative traits in pigeonpea (Cajanus Cajan L. Millsp.). Journal of Food Legumes 25(1): 1-18.

FAOSTAT (2015). http://faostat.fao.org/site/339/ default.aspx

Khorgade, P.W., Wankhade, R.R. and Wanjari, K.B. (2000). Combining ability analysis in pigeonpea using male sterile lines. Indian Journal Agricultural Research 34: 112-116.

Laxmipathi Gowda, C.L., Sushil, K. Chaturvedi., Pooran, M. Gaur., Sameer Kumar, C.V. and Aravind, K. Jukanti (2015). Pulses research and development strategies for india. Pulse hand book 17-33.

Meshram, M.P., Patil, A.N. and Abhilasha, K. (2013). Combining Ability Analysis in Medium Duration CGMS Based Hybrid Pigeonpea (Cajanus cajan (L.) Millsp.,). Journal of Food Legumes. 26(3 \& 4): 29-33.

Nene, Y.L. and Reddy, M.V. (1977). A new technique to screen Pigeonpea for resistance to sterility mosaic. Trop. Grain Legume Bull. 25:28-30.

Sameer Kumar, C.V., Sreelaxmi, C.H. and Kishore Verma, P. (2009). Studies on Combining ability and heterosis in pigeonpea [Cajanus cajan (L.) Millsp.]. Legume Research 32(2): 92-97.

Saxena, K.B. and Sharma, D. (1990), Pigeonpea Breeding. The pigeonpea (Eds. Nene, Y.I., Hall, S.D. and Sheila,V. K.,). 375-399.

Sekhar, M.R., Singh, S.P., Mehra, R.B. and Govil, J.N. (2004). Combining ability and heterosis in early maturing pigeonpea [Cajanus cajan (L.) Millsp.] hybrids. Indian Journal of Genetics and Plant Breeding. 64 (3): $212-216$

Sharma, M., Telangre, R. and Pande, S. (2013). Identification and validation of resistance to fusarium Wilt and sterility mosaic disease in Pigeonpea. Ind. J. Plant Prot. 41(2): 141-146.

Shobha, D. and Balan, A. (2010). Combining Ability in CMS/GMS Based Pigeonpea (Cajanus cajan (L.) Millsp.,) Hybrids. Madras Agricultural Journal. 97 (13): $25-28$.

Singh, I.P., Vishwadhar and Dua, R.P. (2003). Inheritence of resistance to sterility mosaic disease in pigeonpea [Cajanus cajan (L.) Millsp.]. Indian J. Agril. Sci. 73: 414-417.

Singh, I.P. and Srivastava, D.P. (2001). Combining ability analysis in interspecific hybrids of pigeonpea. Indian $J$. Pulses Res., 14(1): 27-30. 
Sony Tiwari. (2010). Estimation of heterosis, combining ability and genetic components for yield and yield attributes in Pigeonpea (Cajanus cajan L.). MSc (Agri) Thesis submitted to UAS, Raichur

Sunil Kumar, Lohithaswa, H.C., Dharmaraj, P.S. (2003). Combining ability analysis for grain yield, protein content and other quantitative traits in pigeonpea. $J$. $M a$ harashtra Agric. Univ. 28(2): 141-144.

Upadhyaya, H.D., Reddy, K.N., Sharma, S., Varshney, R.K., Bhattacharjee, R., Singh, S., Gowda, C.L.L. (2011).
Pigeonpea composite collection and identification of germplasm for use in crop improvement programmes. Plant Genetic Resources. 9:97-108.

Vaghela, K.O., Desai, R.T., Nizama, J.R., Patel, J.D. and Sharma, V. (2009). Combining ability analysis in pigeonpea. Legume Research. 32 (4): 274-277.

Yamanura, Lokesha, R., Dharmaraj, P.S., Muniswamy, S. and Diwan, J.R. (2014). Estimation of Heterosis, Combining ability and Gene action in Pigeonpea [Cajanus cajan (L.) Millsp.]. Elect. J. of Plant. Breed.5(2): 173-178. 